\title{
Katharina Sternek
}

\section{Critical Realism: The Epistemic Position of Gestalt Theoretical Psychotherapy'}

\section{Introduction}

In psychotherapy science, there is a certain general emphasis on the demand that psychotherapeutic approaches reveal and reflect the epistemological views that underlie or are inherent in their understanding of psychotherapy, both in their theoretical concepts and their practice (cf. Buchmann, Schlegel, \& Vetter, 1996). In the portrayals of psychotherapeutic methods, however, one rarely finds an explicit response to this claim. As an example, I am referring to an anthology containing the self-presentation of 50 different psychotherapeutic and psychotherapy-related approaches practiced in Austria (Stumm, 2011a). In his introduction, the editor refers to Petzold's "Tree of Science" (Stumm, 2011b, 13-15) and the necessity that every psychotherapy method must also explicate its basic epistemological assumptions. However, the following descriptions of the various methods in this anthology only in a few cases refer more than peripherally to the epistemological orientation of these various approaches. A similar picture emerges in international compendia (see Corsini \& Wedding, 2010; Lambert, 2013).

If we leave aside those methods and conceptualizations of psychotherapy that do not explicitly deal with their epistemological stance at all, it seems justified to distinguish in the remaining area three main directions of dealing with epistemological questions:

a. The first of these directions addresses the different "epistemic approaches" people prefer to use to obtain clarity about their situation and possibilities [e.g., "phenomenological, dialectical, empirical-analytical, hermeneutical” (Pieringer \& Fazekas, 1996, 229ff)] and then determines which of these approaches is addressed primarily and elaborated in a praxeological way in a given therapeutic method. Wagner, for example, ascribes to the Daseinsanalysis a rather phenomenological epistemic process, to modern psychoanalysis a hermeneutical one, to behavioral therapy an empirical-analytical one and to systemic therapy a constructivist one (Wagner, 2007, 169). Against this background and connected

\footnotetext{
This contribution is based on the lecture at the 21 st International Convention of the Society of Gestalt Theory and its Applications "Motion - Spaces of Human Experience," 13th-15th June 2019, Warsaw, Poland.
} 
to it, there is also a discussion concerning the question of which psychotherapy methods can be effectively integrated with others and which cannot. Buchmann for example, speaks out against a hasty integration of methods which are incompatible in their epistemic approach into a "general psychotherapy," and pleads instead for the explicit presentation and critical reflection of the epistemological positions of the various methods, because: "From these epistemological considerations it seems to be clear that a 'general psychotherapy' that strives for uniformity virtually prevents the further development of psychotherapy." (Buchmann et al., 1996, 108; transl. KS) The same thought is expressed by Norcross \& Newman: "Profound epistemological and ontological differences also impede rapid or wholesale integration." (Norcross \& Newman, 2003, 5) Some heterogeneity of epistemic approaches can also be seen as an opportunity for psychotherapy to develop a "genuine scientific identity" (Slunecko, 1996, 294; transl. KS). Alternatively, in more practical terms, "a core skill needed to be an effective therapist is to have developed an awareness of one's own ontological and epistemological positions in relation to one's work as a therapist.”(Willig, 2019, 1)

b. The second of these directions focuses, above all, on the scope and limitations of human cognition and derives a variety of conclusions from that for many fields of psychotherapeutic practice. In this regard, the most important example is the debate about (radical) "constructivism" first above all in the community of systemic family therapies (cf. Becvar, 2003), which has also radiated into communities of other therapeutic methods. The "constructivist turn" in the debate among the systemic family therapists has focused on the question of the possibilities of insight and their limitations. The experiential world of human beings is seen as a private construction which consequently must be fully acknowledged by the psychotherapeutic approach, e.g., in founding the therapist's attitude of "impartiality" on this, or in understanding therapy as "a form of conducting a conversation" (Stumm, 2011c, 251f; transl. KS), in which the therapist supports the "modification in attribution of meanings." (ibid.)

c. Finally, there is the third direction [to which Gestalt Theoretical Psychotherapy (GTP) belongs - but probably also to a large extent Petzold's Integrative Therapy], which brings together both previously mentioned directions based on an explicit ontological position (about the human being, human life, the human organism, and the human community) and thus bases the entire system of therapy theory and the entire practice on this epistemological position. In this sense, Petzold calls for a consistent scientific approach to method-integration in psychotherapy, in which "clarity of the epistemological standpoint" is one of the central criteria (Petzold, 2011, 267). In relation to GTP, Stemberger characterizes this position as follows: "If one compares the therapy theory of GTP with that of other methods, it is striking that in its 'conceptual architecture' the foundation 
is not a specific praxeology, psychopathology or the like, but a specific epistemological position. This, the so-called Critical Realism (CR) (Köhler, 1968; Bischof, 1966), is the basis for further core concepts of GTP. In GTP, CR is also a fundamental anthropological position - a differentiated statement about man and his world." (Stemberger, 2011, 219f; transl. KS)

Any psychotherapy faces the challenge that besides externally observable behaviors, conditions, and messages of clients, there are obviously "internal processes" that are not directly accessible to the therapist. Psychotherapeutic approaches understand and conceptualize differently this relationship between such an "Inside" and "Outside". From these are drawn representations regarding personality, psychic disorders, as well as appropriate therapeutic treatment. In the following, I shall present the basics of CR, and thereafter the consequences will be outlined. The latter ones result from a particular approach for the understanding of human behavior, the therapeutic attitude and relationship, as well as praxeology.

\section{Critical Realism}

The epistemological position of GTP is based on CR, as it was formulated first by Köhler, 1929; Koffka, 1935; Köhler, 1938; Metzger, 1941 and further elaborated and differentiated by Bischof, 1966 and Tholey, 1980.

From an ontological angle, Gestalt theory takes a monistic position on the psychophysical problem (i.e., in simple terms, it advocates the unity of body and soul), but from an epistemological point of view, it takes a dualistic position (Köhler, 1971, Tholey, 1986/2018). Concerning epistemological dualism, the central premise of CR emphasizes the clear distinction between the trans-phenomenal world and the phenomenal world. Early experimental results of Gestalt psychology investigated and proved the difference between physical facts and perception, such as Wertheimer "studying the relationship between the organization of the geographical ${ }^{2}$ and phenomenal fields." (Luchins \& Luchins, 1999, 216)

The trans-phenomenal world encompasses the macrocosm of the physical world and all physical objects and physical organisms which are embedded therein. It is to be understood as the world and a reality that cannot be accessed directly by people. What can be deducted, hypothesized, and said about the transphenomenal world is the interpretation of data obtained with phenomenal means, theoretical constructions, and models. Their data and results constitute the "critical-phenomenal worldview" (Bischof, 1966, 28ff) in contrast to the "naïve-phenomenal world" of our everyday life experience. However, within this

\footnotetext{
2 The term "geographical" world, which Koffka proposed for the physical macrocosm in 1935, is somewhat misleading according to Metzger, because the science of geography is also part of the phenomenal world (Metzger, 2001, 305). For an understanding of the terms "physical," "transphenomenal," and "reality in the first sense," see Walter (2001).
} 
physical macrocosm, each person (just as every conscious being) has his/her own microcosmic phenomenal world, which he/she perceives and experiences as reality. It is the world that faces every individual and it is intuitively accessible to him/her. The phenomenal world stands for the entire world which man experiences: The phenomenally experienced bodily ego and the phenomenal environment which includes the other people.

Based on the distinction of CR one speaks of a "doubling of the world" (the concept of epistemological dualism) and one can act on the assumption that the phenomenal world "represents" the trans-phenomenal world in a more or less adequate way, but not like a "passive image" (it is thus a representational approach to cognition, but one that goes far beyond a mere representational function of consciousness, as will be shown). As Tholey argues (Tholey, 1986/2018, 247), this representational effect rather constitutes the end result of a complex process, which can be described as follows: Physical stimuli from the physical environment meet our physical senses and enter (as well as proprioceptive stimuli from the physical body) via afferent neural pathways into the brain to an area in the cerebral cortex, for which Gestalt psychologist Wolfgang Köhler used the term "psychophysical level" (cf. Köhler, 1938/1968). At the psychophysical level (PPN) based on physical-physiological processes, a transformation of the stimuli takes place, as a result of which certain contents can be experienced psychologically. In his research, Köhler formulated the so-called "isomorphism assumption." Isomorphism assumes that there is a structural equivalence between physical and physiological processes (brain operations) and psychological operations. This means that for every phenomenon in the experience of the individual there is a corresponding neurophysiological event in the sense of a central nervous counterpart. As a consequence, we have as well to differentiate between our physical organism and our phenomenal body-ego. Therefore, the question as to why we perceive other persons and objects in front of our perceived bodily ego, could be answered as Köhler (1929) did.

Concerning the relationship between the physical world and the phenomenal world, one also assumes a structural equivalence between the physical world and the phenomenal world. "Wertheimer is pointing out that there are resemblances between perception and external world.” (Luchins \& Luchins, 1999, 216) The isomorphism hypothesis, however, can neither be proved nor disproved. I nonetheless would like to mention the debate between Eagle \& Wakefield (2007) and Cali (2007) about the relationship of isomorphism with the mirror neuron system. Eagle\&Wakefield thereby refer to "historical antecedents" of the idea of isomorphism. (cf. Eagle \& Wakefield, 2007, 173f) Since the early beginnings of Gestalt psychology several decades ago, the psychophysical approach of $\mathrm{CR}$ alludes to topics which are recently discussed anew, again in 
the current discourses of "embodied" and "enacted" cognition. As Clark says, "Human sensing, learning, thought, and feeling are all structured and informed by our body-based interactions with the world around us." (Clark, 2012, 275)

From a practical viewpoint, the isomorphism assumption of structural similarity is useful because it explains why human beings are able to move in the physical environment and to interact with this environment, including their fellow human beings, according to their needs. In this sense, the function of the phenomenal world can be regarded as the "steering organ" (cf. Metzger, 1986), which supports the orientation of man in the physical world. Elsewhere, I elaborated the following example (see Sternek, 2018): While running a man hurts his physical foot by bumping his physical foot against a physical tree root, although he has seen that he has put his experienced foot far from the experienced tree root. The painful feedback shows that there is a difference and mismatch between the position of the physical foot in the physical world and the experienced foot in the experienced world. In our everyday lives, our phenomenal world is generally presented to us as the only real thing - but there are always experiences or perceptions in this phenomenal world that indicate the existence of a trans-phenomenal world.

The example moreover illustrates as well the relationship between the transphenomenal and phenomenal world. It is evident that there exists an interaction between the trans-phenomenal part of the physical world and the phenomenal part of the physical world. While the physical organism of a person moves in the physical world, his/her phenomenal world is open to influences from the physi$\mathrm{cal} /$ trans-phenomenal world.

CR also maintains that the phenomenal worlds of human beings are different. Despite the same basic facts in the physical world, different experiences emerge in the phenomenal worlds of people. For example: If we hear several persons or eyewitnesses who have observed an automobile accident, we often have a conflict of statements, which normally is not evoked by predilections. This aspect is of particular importance for psychotherapeutic work because it supports our knowledge about differences in the perception of situations, which build the base for experience and interpretation of situations and interactions. Many conflicts arising in relationships, for example, "who is right," can be understood as a consequence of the differences within the phenomenal world of people. In the field of psychotherapy, by working with a patient suffering from an eating disorder, who says "I know that I am thin, but I feel thick, Fuchs illustrated in a comprehensible way how useful the CR perspective can be in obtaining an understanding of the patient's view. (Fuchs, 2014, 130)

The differences between the phenomenal worlds also arise because the operations in the phenomenal worlds are field events. The phenomenal world is organized as 
a dynamic field in such a way that all the experience and behavior of the person depends on the field forces between the person and the environment (cf. Lewin, 1951). Due to the action of various attractive or repulsive forces, objects in the phenomenal world of a person have a positive or negative character - a "Valenz" - of prompting in accordance with the states of tension determined by personal needs and intentions (see Lindorfer, 2021). In this sense, the phenomenological approach of GTP is completed by the field-analyses which support our insight for dynamic processes.

However, as we all know, people can speak about their perceptions and their experiences, and they can as well share experiences. As a matter of fact, it is true that despite all the differences between their experiences "their phenomenal worlds [...] are structured by fundamentally similar principles and work in a similar way" (Stemberger, 2016, 34; transl. KS). These correspondences in structure and function are the precondition for communication between the individuals and thus form the basic requirement for psychotherapeutic work.

\section{Conclusions for Psychotherapeutic Work}

This epistemological position immunizes GTP against mono-personal views of the human being or of the psychotherapeutic relationship: GTP is therefore a primarily social and relationship-oriented approach. Compared to other socialpsychological approaches, GTP is characterized by the fact that it regards humans as primarily social beings and not as individuals onto whom social relationships and determinations "are added" only secondarily. Therefore, GTP also assumes that psychic problems arise in the majority of cases, or indirectly, from troubles in people's social life and their relationships. Some further conclusions that can be drawn from the CR model for practical psychotherapeutic work will now be presented. First, we discuss conclusions for the basic psychotherapeutic attitude and the psychotherapeutic relationship, which is followed by conclusions concerning praxeology.

\subsection{Basic attitude of GTP}

Tholey characterizes the basic position of CR as follows:

"(1) Besides the phenomenal world in which I am, finding things and events, in which I think, feel, make decisions, and communicate with other people who, like me, exist with 'body and soul,' there is one transgressive 'trans-phenomenal' world, which can be subdivided into my physical organism and a physical environment.

(2) In the physical environment are other organisms that have their own phenomenal worlds."(Tholey, 1986/2018, 246; transl. KS) 
According to Tholey, the acquisition of the second assumption includes "an ethical motive," namely that, if the possibility exists that other beings have a "consciousness," this obliges me to behave in such a way "as if they were consciousness gifted"(ibid.).

As CR expects that a common trans-phenomenal world exists which contains other human and non-human animals, our model is linked to ethical demands. To see other people as conscious subjects means that we have to treat them accordingly (Tholey, 1986/2018). This requires us to be constantly aware that other people each have their own phenomenal world so that their experience might be different from our own experience. This awareness promotes an attitude of respect for the individual world and the reality of others, especially that of our clients. Because of this attitude, Giuseppe Galli designated GTP as a "school of respect" (cf. Galli, 1999, 25). The basic attitudes of respect and objectiveness toward clients indeed characterize GTP. Furthermore, the CR stance is connected to the insight that our actions do not only exist in our phenomenal worlds but also interfere with the trans-phenomenal world that we share with our fellow human beings. This aspect calls for our human responsibility regarding our behavior.

\subsection{Psychotherapeutic relationship(s)}

Our fundamental conceptualization of the therapeutic relationship, to which a particular effectiveness in psychotherapy is attributed across all schools, is also marked by the critical-realistic perspective.

In a naïve-realistic representation, that is common in everyday life, and as one may read in some conventional psychotherapeutic case presentations, one assumes a therapeutic relationship or situation - that means one therapeutic relationship and one situation. From a critical-realistic point of view, however, as described in detail by Stemberger (2016), there are at least two therapeutic situations: The therapeutic relationship or situation in the phenomenal world of the therapist and the therapeutic relationship or situation in the phenomenal world of the client (Fig. 1).

Both the phenomenal world of the therapist and the phenomenal world of the client include one therapist and one client. Stemberger writes: "In the phenomenal world of the client, in this situation, the experienced ego of the client faces his/her phenomenal therapist, and in the phenomenal world of the therapist, the phenomenal ego of the therapist faces his/her phenomenal client." (Stemberger, 2016, 33; transl. KS) This approach is constitutive for the entire therapeutic process. Accordingly, a permanent readiness is required for mutual exchange between client and therapist about their reciprocal experience - not one restricted to 


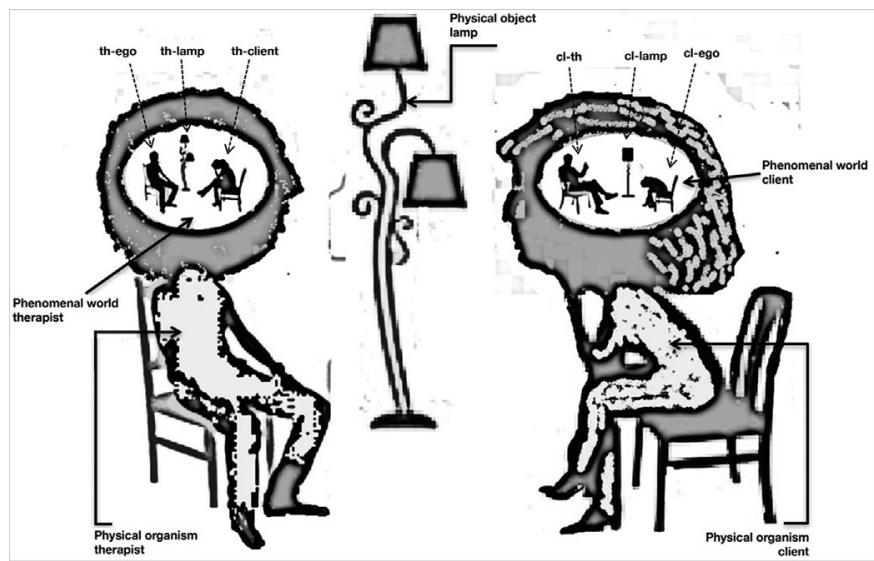

Fig. 1. The therapeutic situation from the critical-realistic perspective (cf. Stemberger, 2016, 33) th-ego: phenomenal ego of therapist; th-cl: phenomenal client of the therapist; th-lamp: lamp in the phenomenal world of the therapist. cl-ego: phenomenal ego of the client; cl-th: phenomenal therapist of the client; cl-lamp: lamp in the phenomenal world of the client.

conflict between the parties. Although both are in a common trans-phenomenal world and therefore interact with each other, they sometimes experience events in psychotherapy very differently. Therefore, the therapist needs to be aware of these differences. An awareness of these differences should support him/her to reflect critically his/her own perception of the therapeutic relationship, in combination with the awareness being mistaken regarding the quality of this relationship.

Considering the eminent importance of the therapeutic relationship for the success or failure of psychotherapeutic work, a further question is central: How do I as a therapist appear and act in the phenomenal world of the client, that is, how am I experienced by the client (as a supportive therapist, as a critical or judging therapist, as a comforting therapist, ...). Conversely, just as important too is the question of how the client appears in my phenomenal world (as a difficult, acting client, as a client who puts a lot of strain on me, as a client who annoys me, or as an admiring client, ...). According to the CR standpoint of GTP, this question cannot only be answered by the concept of transference or countertransference (cf. Kästl, 2007).

In summary, the CR perspective thus shapes the overall attitude of the therapist in his/her interaction with the client. It contributes to promote an attitude of the therapist, to critically deal with his/her own experience and evaluation of the therapeutic relationship and the therapeutic situation, followed by an effort for open, transparent, communication and mutual coordination. As language plays an important role within communication, therapists should train their sensitivity 
for language, especially for the "double meaning of hybrid terms and shift-ofsituations." (cf. Buchholz, 2020, 127).

At least, adequately internalized, the CR perspective and the associated basic attitude may represent protection for the therapeutic relationship: It protects the client's dignity as her/his experience is encountered with respect. Furthermore, it protects the client from the alleged superiority of the therapist and the therapist from being seduced by fantasies of omnipotence. In contrast to some asymmetry that could arise with a particular comprehension of the roles of client and therapist - on the one hand, a client who sees himself/herself as seeking help, and on the other hand, a therapist who imagines himself to be allocated a special power ostensibly resulting from the deemed sovereignty of interpretation which is, by default, assigned to therapists by reason of the subjective nature of psychotherapeutic practice - transparent interactions between therapist and client can counteract the reinforcement of imaginary hierarchies of power, as well as their narcissistic abuse.

\section{Praxeology}

As a consequence, the CR approach exerts influence on the praxeology: A centerpiece of praxeology of GTP is the phenomenological approach, followed and completed by the field analysis. (see Stemberger, 2016)

When we talk about the therapist "practicing phenomenology together with his client," we say that the therapist encourages his client to take his own phenomenal world seriously and tries to help the client to explore his/her phenomenal world not only with the help of logical reasoning, but "with all his/her senses" - a world with field character (in which attractive and repulsive field forces are effective) to support the client to clarify his/her situation and possibilities for action.

In the context of his field theory, Kurt Lewin writes that this is genuinely a psychological approach: "One of the basic characteristics of field theory in psychology, as I see it, is the demand that the field which influences an individual should be described not in 'objective physicalistic' terms, but in the way in which it exists for that person at that time."(Lewin, 1951, 62)

Lewin even emphasizes: "A teacher will never succeed in giving proper guidance to a child if he does not learn to understand the psychological world in which that individual child lives. To describe a situation 'objectively' in psychology actually means to describe the situation as a totality of those facts and of only those facts which make up the field of that individual. To substitute for that world of the individual the world of the teacher, of the physicist, or of anybody else is to be, not objective, but wrong." (ibid.) 
In this context, Lewin agrees with CR to the extent he refers to Koffka's distinction between the "behavioral environment" of man and his "geographical environment" (cf. Koffka, 1935, 27f). As early as 1935, Koffka demonstrates with the story "The ride over the Lake of Constance" that experience and behavior of a human being are determined by the behavioral environment (phenomenal world) and not by the "geographical," physical environment.

GTP too confirms that the individually experienced world is a decisive factor in determination of the client's experience and behavior. Therefore, within the psychotherapeutic work, we focus our questions and interventions on the analyses of the phenomenal world. As a consequence of the therapist's psychotherapeutic work, a change of centering (see Fuchs, 2021) in the phenomenal world of the client happens in such a way that he/she is enabled to solve his/her problems. Therefore, practicing phenomenology means to jointly explore the client's phenomenal world; to be more precise, it involves supporting the client in exploring her/his phenomenal world, since the latter is not imminently accessible to the therapist, but only indirectly through constant exchange with the client. During the therapeutic process, the therapist - monitoring his/her phenomenal perspective to try to understand the client and to notice inconsistency and contrariness can offer his/her perspective to the client to the extent that it supports the client's development.

The Gestalt psychologist Metzger described several differentiations within the phenomenal world. The most important differentiation for the practical dimension of therapeutic work is the following one: Regarding the immediate experience, Metzger discriminates between what is directly encountered, bodily encountered and facing us, and what is brought to mind, thought, suspected, remembered, planned, constructed, conceptualized, or expected (cf. Metzger, 2001, 8-47).

Indeed, some former Lewin students (Brown, 1933; Mahler, 1933) have demonstrated in various studies that what is experienced in the direct encounter is "more real," and in many cases more effective, for behavior than the merely thought of or visualized experience. For example: It makes a huge difference to a person, whether he/she knows intellectually that his/her fear can be traced back to the memory of certain past or future events or whether he/she encounters that fear directly in his/her experience. One consequence which falls within the scope of our psychotherapeutic work is that we can assist our client to face his/her fear in "the here and now," not only by talking about it, but also by processing and overcoming it within a setting of supporting conditions and interventions.

In our psychotherapeutic work we use our knowledge about Metzger's distinction by offering experience-centered interventions (e.g., working with the empty chair, 
body awareness exercises), as long as we intend to support the client by making contact with his/her immediate zone of experience. For example, working with the empty chair can enable clients to empathize with the encountered other and to experience how the other feels. At best, the client gains more insight into the dynamic of the motives and the relation. However, there are also circumstances in which the opposite of direct confrontation is required, such as working with traumatized people who suffer from flashbacks or intrusive memories. These cases require targeted interventions that help those affected to obtain a greater distance from their immediate experience [e.g., screen-technic (see Sternek, 2014)]. The essential advantage of a clear distinction is therefore - if the therapist notices what is at stake - the clarity with which the choice of appropriate interventions is exercised.

However, this does not mean that in GTP no importance is attached to the world of thoughts, ideas, the known, and the believed. There is rarely, if ever, an immediate perception that is not consciously or non-consciously influenced by ideas and concepts (whether scientifically based or not). Further differentiation is therefore important, namely Bischof's distinction between the naïve-phenomenal and the critical-phenomenal world (cf. Bischof, 1966, 28ff.). For Bischof, the naïve-phenomenal world refers to the perceptual world of everyday experience, that is, the experienced bodily ego and experienced environment. In contrast, the critical-phenomenal world means all known facts, research findings, and assumptions regarding the body schema, the world schema, the organism, the physical world, etc., whether these are scientific insights or everyday assumptions of laypeople. Stemberger points out that "all own explanations for the relationship in the world belong to the critical-phenomenal world,... all beliefs, convictions, and ideologies, including all related problems, doubts, and pricks of consciences." (Stemberger, 2016, 32; transl. KS)

As psychotherapists, we sometimes meet clients who suffer from problems which are predominantly based on fixed assumptions. For example, one female client, who wishes to have a satisfying partnership, which does not happen, says: "I know that at least all guys are liars who use their phrases only to impress women. But in fact, they have simply one thing in mind, to manipulate and use women." This basic conviction then - in the sense of a "naïve theory" (cf. Heider, 1958) - influences the experience and behavior of the person concerned. There is a mutual influence or superposition of the naïve-phenomenal world and the critical-phenomenal world. Such a "theory about the nature of male human beings" contributes under certain circumstances to particular problems that arise as the result of circumstances and inhibits the chances of finding solutions for them. In the light of her "theory" about man, the woman in our example cannot really meet a man without distrust and prejudice. In such and similar cases, 
psychotherapeutic work can not only deal with the naïve-phenomenal world and the experience of a human being, but must also address his (or her) self-assumed convictions and explanatory models.

Accordingly, the non-observance or neglect of the everyday explanations of our clients would appear as an omission. One must not refuse all of this with arguments like intellectualism or rationalism. To do justice to our clients in psychotherapy, the "practicing of phenomenology" (Stemberger, 2016, 34f) necessitates the inclusion of both the critical-phenomenal world as well as the naïvephenomenal world of the client. As psychotherapists, we should be encouraged to reflect on the question of whether and how far our beliefs and theories may unconsciously influence our perception, evaluation, and behavior. At this point I fully agree with Willig's demand that "a core skill needed to be an effective therapist is to have developed an awareness of one's own ontological and epistemological position in relation to one's work as a therapist." (Willig, 2019, 1) Furthermore, in general, it seems to be clear that the similarity of the basic assumptions of the therapist and the client support the understanding of a client's distress (ibid.). However, there is one point in which I differ from Willig's claim "that client and therapist share assumptions about the nature of human being and experiencing" (ibid., 2), because within the mutual exchange, the difference, if it is not too radical, could also be regarded as conducive for the therapeutic process.

Finally, some short comments concerning diagnosis need to be provided. The CR perspective can protect against acceptance of diagnostic classification that is based on a pragmatic agreement or on an ultimately untenable self-conception about reality. Our clients derive little benefit from such a classification. On the contrary - classifications can imply that we no longer consider some things to be worthy of clarification. (cf. Beneder, 2015). Therefore, the CR approach can support us to meet our clients in as unbiased a manner as possible.

\section{Final Remark}

The epistemological position of CR offers an explanatory model of how differences in the perception and experience of people arise, and thereafter also conflicts. This epistemological background is useful because it contributes to a better understanding of dynamic interactions in social relationships. Hence, it supports the formation of a constructive relationship in the field of psychotherapy and in all other areas in which people try to constructively support each other. Several tasks are connected to this objective, in particular the aim of doing justice to the clients who have entrusted themselves to the care of the psychotherapist to bring about an improvement in their reality of life and experience, and this is not in the least a question which concerns the prerequisites and possibilities of our knowledge. Finally, it should be comprehensible that the system of therapeutic 
theory and practice of GTP achieves the demand of being based on a clear epistemological position.

\section{Summary}

In this contribution, I discuss the relevance of epistemological models for psychotherapy. Despite its importance epistemology is seldom explicitly dealt with in the psychotherapeutic landscape. Based on the presentation of "Critical Realism (CR)," the epistemological position of Gestalt Theoretical Psychotherapy (GTP), I intend to show to which extent this explanatory model supports a differentiated understanding of problems between human beings, arising from the differences in experiencing "reality." The presentation deals explicitly with some conclusions that can be drawn from the CR model for practical psychotherapeutic work. In particular, the aspects of basic therapeutic attitude, therapeutic relationship, and praxeology are highlighted.

Keywords: epistemology, critical realism, therapeutic attitude, therapeutic relationship(s), praxeology.

\section{Zusammenfassung}

Dieser Beitrag diskutiert die Relevanz erkenntnistheoretischer Modelle für die Psychotherapie. Trotz ihrer Bedeutung werden erkenntnistheoretische Fragen in der psychotherapeutischen Landschaft nur selten explizit behandelt. Vor dem Hintergrund der Darstellung des "Kritischen Realismus", der erkenntnistheoretischen Grundlage der Gestalttheoretischen Psychotherapie, soll gezeigt werden, in welchem Ausmaß dieses Erklärungsmodell zum Verständnis zwischenmenschlicher Probleme, die auf dem unterschiedlichen Erleben der "Wirklichkeit" beruhen, beitragen kann. Die Darstellung behandelt die Schlussfolgerungen, die sich aus dem kritisch-realistischen Modell für die psychotherapeutische Praxis ergeben, wobei besonders Aspekte der therapeutischen Haltung, therapeutischer Beziehung(en) und therapeutischer Praxis beleuchtet werden.

Schlüsselwörter: Erkenntnistheorie, Kritischer Realismus, therapeutische Haltung, therapeutische Beziehung(en), Praxeologie.

\section{References}

Becvar, D. S. (2003). Eras of epistemology: A survey of family therapy thinking and theorizing. In: Sexton, T. L., G. R. Weeks, M. S. Robbins (Eds.), Handbook of family therapy. New York and Hove: Brunner-Routledge, 3-20.

Beneder, D. (2015). Gestalttheorie und Diagnostik in der Psychotherapie. Eine kommentierte Auswahlbibliographie. Phänomenal, 7(2), 51-55.

Bischof, N. (1966). Erkenntnistheoretische Grundlagenprobleme der Wahrnehmungspsychologie. In: Metzger, W. \& H. Erke (Hrsg.), Wahrnehmung und Bewusstsein, Handbuch der Psychologie, Bd. 1/1. (pp. 21-78). Göttingen, Germany: Verlag für Psychologie.

Brown, J. F. (1933). Über die dynamischen Eigenschaften der Realitäts- und Irrealitätsschichten. Psychologische Forschung, 18(1/2), 2-26.

Buchholz, M. B. (2020). Seeing the situational Gestalt-movement in therapeutic spaces. Gestalt Theory, 42(2), $101-132$.

Buchmann, R., Schlegel, M., \& Vetter, J. (1996). Die Eigenständigkeit der Psychotherapie in Wissenschaft und Praxis. In: Pritz, A. (Hrsg.), Psychotherapie - eine neue Wissenschaft vom Menschen. Wien: Springer, 75-122.

Cali, C. (2007). Isomorphism and mirror neuron system. Commentary Article on Eagle, M. N. \& Wakefield J. C., Gestalt Psychology and the Mirror Neuron Discovery. Gestalt Theory, 29(2), 168-173. 
Clark, A. (2012). Embodied, embedded, and extended cognition. In: Frankish, K. \& RW. M. Ramsey (Eds.), The Cambridge handbook of cognitive science. Cambridge: Cambridge University Press, 275-291.

Corsini, R. J., \& Wedding, D. (2010). Current Psychotherapies (9th Edn). Belmont, CA: Brooks/Cole.

Eagle, M. N., \& Wakefield, J. C. (2007). Action Potentials and Representationality: Reply to Dr. Cali's Commentary. Gestalt Theory, 29(2), 173-175.

Fuchs, Th. (2014). Die praktische Seite einer Erkenntnistheorie: Zur Entwicklung einer angemessenen therapeutischen Haltung in der Arbeit mit essgestörten Menschen. Gestalt Theory, 36(2), 129-140.

Fuchs, Th. (2021). Gestalt theoretical psychotherapy - A clinical example. Gestalt Theory, 43(1).

Galli, G. (1999). Psychologie der sozialen Tugenden. Wien; Köln; Weimar: Böhlau Verlag

Heider, F. (1958). The psychology of interpersonal relations. Hillsdale, New Jersey: Erlbaum. (deutsch 1977: Psychologie der interpersonellen Beziehungen. Stuttgart: Klett Cotta).

Kästl, R. (2007). Gestalttheoretische Überlegungen zum psychoanalytischen Konstrukt „Übertragung“. Gestalt Theory, 29(1), 65-73.

Koffka, K. (1935). Principles of Gestalt psychology. New York, NY: Harcourt-Brace.

Köhler, W. (1929). Ein altes Scheinproblem. Die Naturwissenschaften, 17, 395-401. English translation by Erich Goldmeier: An old pseudo-problem. In: Henle, M. (Ed.), The Selected Papers of Wolfgang Köhler (pp. 125-141). New York, NY: Liveright.

Köhler, W. (1968). Werte und Tatsachen. Heidelberg: Springer. (Original 1938: The Place of Value in a World of Facts. New York, NY: Liveright).

Köhler, W. (1971). Die Aufgabe der Psychologie. Berlin-New York: De Gruyter. (Original 1969: The Task of Gestalt Psychology. Princeton University Press).

Lambert, M. J. (Ed., 2013). Bergin \& Garfield's handbook of psychotherapy and behavior change (6th edn.). Hoboken, NJ: Wiley.

Lewin, K. (1951). Field theory and learning. Field theory in social science. Selected theoretical papers (pp. 60-86). New York, NY: Harper \& Brothers.

Lindorfer, B. (2021). Personality theory of Gestalt theoretical psychotherapy. Kurt Lewin's field theory and his theory of systems in tension revisited. Gestalt Theory, 43(1).

Luchins, A., \& Luchins, E. H. (1999). Isomorphism in Gestalt theory: Comparison of Wertheimer's and Köhler's Concepts. Gestalt Theory, 21(3), 208-234.

Mahler, W. (1933). Ersatzhandlungen verschiedenen Realitätsgrades. Psychologische Forschung, 18(1/2), $27-89$.

Metzger, W. (1941). Psychologie. Die Entwicklung ihrer Grundannahmen seit der Einführung des Experiments. 1. Auflage. Dresden/Leipzig: Steinkopff.

Metzger, W. (1969/1986). Die Wahrnehmungswelt als zentrales Steuerungsorgan. In: M. Stadler \& H. Crabus (Hrsg.), Gestaltpsychologie. Ausgewählte Werke (pp. 269-279). Frankfurt am Main, Germany: Verlag Waldemar Kramer.

Metzger, W. (2001). Psychologie. Die Entwicklung ihrer Grundannahmen seit der Einführung des Experiments. 6. Auflage. Wien, Austria: Verlag Wolfgang Krammer.

Norcross, J. C., \& Newman, C. F. (2003). Psychotherapy integration. Setting the context. In: Norcross, J. C. \& M. R. Goldfried, M. R. (Eds.), Handbook of psychotherapy integration. New York \& Oxford: Oxford University Press, 3-45.

Petzold, H. (2011). Integrative Therapie. In: Stumm, G. (Hrsg.). Psychotherapie. Schulen und Methoden. Eine Orientierungshilfe für Theorie und Praxis. 3. Auflage. Wien: Falter Verlag, 267-276.

Pieringer, W., \& Fazekas, Ch. (1996). Die vier primären Erkenntnismethoden als wissenschaftliche Leitlinien für die Selbsterfahrung in der Psychotherapieausbildung. Psychotherapie Forum, 4(4), 229-238.

Slunecko, T. (1996). Einfalt oder Vielfalt in der Psychotherapie. In: Pritz, A. (Hrsg.), Psychotherapie - eine neue Wissenschaft vom Menschen. Wien: Springer, 293-321.

Stemberger, G. (2011). Gestalttheoretische Psychotherapie. In: Stumm, A. (Hrsg.), Psychotherapie. Schulen und Methoden. Eine Orientierungshilfe für Theorie und Praxis. 3. Auflage. Wien: Falter Verlag, 218-227.

Stemberger, G. (2016). Phänomenologie treiben. Phänomenal, 8(1), 30-35.

Sternek, K. (2014). Über den Einsatz und die Wirkungsweise von "Bildschirm-Techniken”. Phänomenal, 6(1), 20-29.

Sternek, K. (2018). Vom Nutzen erkenntnistheoretischer Modelle für die Psychotherapie. Phänomenal, 10(1), $15-24$

Stumm, G. (2011a). Einleitung. In: Stumm, G. (Hrsg.), Psychotherapie. Schulen und Methoden. Eine Orientierungshilfe für Theorie und Praxis. 3. Auflage. Wien: Falter Verlag, 10-34. 


\section{Sternek, The epistemic position of critical realism}

Stumm, G. (2011b). Systemische Verfahren. In: Stumm, G. (Hrsg.). Psychotherapie. Schulen und Methoden. Eine Orientierungshilfe für Theorie und Praxis. 3. Auflage. Wien: Falter Verlag, 251-252.

Tholey, P. (1980). Erkenntnistheoretische und systemtheoretische Grundlagen der Sensumotorik aus gestalttheoretischer Sicht. Sportwissenschaften, 10, 7-33.

Tholey, P. (1986/2018). Deshalb Phänomenologie! In: Tholey, P. Gestalttheorie von Sport, Klartraum und Bewusstsein. Ausgewählte Arbeiten, herausgegeben und eingeleitet von G. Stemberger. Wien: Verlag Wolfgang Krammer, 244-268.

Wagner, E. (2007). Epistemologie. In: Stumm, G. \& A. Pritz (Hrsg.), Wörterbuch der Psychotherapie. Wien: Springer, 169.

Walter, H.-J. (2001). Zur Bedeutung der Begriffe „Physikalisch“, „Transphänomenal“ und „Wirklichkeit im 1. Sinne“. Gestalt Theory, 23(2), 102-112.

Willig, C. (2019). Ontological and epistemological reflexivity: A core skill for therapists. Counselling and Psychotherapy Research, 19(3), 186-194.

Katharina Sternek: is a psychotherapist and a supervisor as well as trainer in Gestalt Theoretical Psychotherapy. She is based in Vienna and is a member of the executive committee of the Austrian Association of Gestalt Theoretical Psychotherapy (ÖAGP) and of the board for training and evaluation of the ÖAGP. Also, she is co-editor of Phänomenal - Zeitschrift für Gestalttheoretische Psychotherapie.

Address: Österreichische Arbeitsgemeinschaft für Gestalttheoretische Psychotherapie, Fünfhausgasse 5/20, 1150 Wien (Vienna), Austria.

Email: sternek@sternek-psychotherapie.at

ORCID: 0000-0003-2170-8393

Affiliation: Österreichische Arbeitsgemeinschaft für Gestalttheoretische Psychotherapie (ÖAGP) 